\title{
Socio-Cultural Transformation of Gadaba Tribes
}

\author{
Dr. Bijayalaxmi Dash*
}

Asst. Professor Department of Odia Ravenshaw University Odisha, India

DOI: $10.36347 /$ sjahss.2020.v08i01.001

| Received: 03.01.2020 | Accepted: 10.01.2020 | Published: 14.01.2020

*Corresponding author: Dr. Bijayalaxmi Dash

Abstract

Tribal society is an enigma to the world of the cultural heritage and they are considered as the original inhabitants of India. The puzzle variety of languages, economy, and way of living is fully mirrored in their culture. Our state Odisha has a great diversification of tribal population. The bright heritage of tribal's of Odisha has made the state culturally extravagant. Because koraput is the polestar of tribal's. Gadaba tribe is one of among them. Gadaba tribe has gone through speedy socio-cultural transformation in contemporary days under the collision of both traditional and modern factor of social change. This interesting colorful mosaic culture will keep up to magnetize the scholars of literature, social scientists the poets and novelists also. This paper attempts to portray the past cultural heritage of Gadaba tribes. Time has come to be cognizant of the pertinence of these social vigorous for examining the present status of Gadaba community. Keeping this in mind the present paper has made a comprehensive document of this indwelling and cherished surface of Gadaba tribal endowment.

Keywords: Puzzle variety, mirrored, diversification, extravagant, polestar, collision, mosaic, magnetize, portray, cognizant, social vigorous, Indwelling, cherished.

Copyright @ 2020: This is an open-access article distributed under the terms of the Creative Commons Attribution license which permits unrestricted use, distribution, and reproduction in any medium for non-commercial use (NonCommercial, or CC-BY-NC) provided the original author and source are credited.

\section{INTRODUCTION}

Gadaba tribe, one of the lesser known tribe of India. By nature, the Gadabas are submissive, candid and conscientious. They are closely connected with the nature that stimulates them to escort a relaxed life. They feel pleasure in wandering about jungles and hilly areas. Natural world makes them familiar with the habitats. Still then they are backward. Their backwardness is the result of centuries of superstition, Separation from urban society and out of reach to basic education. Gadaba society is a stable yet vital and magnetic also. Determination and transpose are the two basic hallmark of Gadaba society. Socio-Cultural changes identified in Gadaba society are unpremeditated as well as motivated. In course of time, Gadabas have accomplished distinct processes of Socio-Cultural transformation, under the footprint of modern and conservative factors of change. Urbanization, Industrialization, Social movements, globalization, education and govt. planning has actively influencing Gadaba's way of life. Various types of govt. plan and policy Intervention and implementation of projects have played vital role for the all-round development of the tribal community as well as socio-cultural changes.

Keywords: Candid, conscientious, habitats, transpose, stimulates, hallmark, unpremeditated, footprint intervention.

\section{Name and origin of Gadaba Tribes}

The constitution SC and ST order, Orissa (amendment) 1976 enlisted 62 tribal communities. Gadaba community is one among them. They are seen in the hilly areas of Andhra Pradesh, Odisha and Madhya Pradesh. In Odisha, They are seen mostly in Koraput, Malkangiri, Nabarangpur, Kalahandi, Rayagada, Khordha, Nayagada and Sundergarh. In Koraput Gadabas are found in Semiliguda, Nandapur, Lamtaput, Pottangi, Koraput and Jaypore also.

About the aboriginality of the Gadaba tribes, different views have been expressed by different scholars. The Gadaba tribe is of an "Austro-Asiatic origin" [1]. The story regarding the origin of Gadaba tribes goes like this. There is no exact error free theory is alive to prove the root of Gadaba community. However, the Gadaba are considered as one of the most primitive tribes of India and track down their origin to the time of Ramayana. During the Epic period, they reside in the south of Dandaka forest region.

In Puranas they have been referred to have accommodation in the Vindhya Range. The studies of folk tales among the Gadaba reveals that they betray their fore fathers, migrated from the river banks of 
Godavari and reconcile in Nandapur, the foregone capital of the King of Jaypore [2]. It is also said that Gadabas emigrated from the Godavari basin to reconcile ultimately in Gadabapada, a village of Lamtaput block of Koraput. Again they have migrated and search for land in the different places of Koraput.

They derive their community name either from Godavari, the river flowing through Andhra Pradesh or from Goda, an odia word meaning 'A brook' or 'Stream' called 'Gadda' in Telugu and 'Gad' in odia. They are sub-divided into five groups known as the Bodo Gadaba, the Sano Gadaba, the parenga Gadaba, the ollar gadaba and kapu Godaba. Amongest those, the Bodo gadaba are more advanced and more skillful to other communities.

According to Bell [3] who wrote the $1^{\text {st }}$ edition of Koraput district Gazetteer noted that there are three sub-divisions of the Gadaba in Koraput , Viz, Bodo, Sano and Ollar. Among three Ollar Gadaba was described by him to be a small group. They spoke Dravidian Language. Their outermost appearances have a similarity with other Mundari speaking Godabas.

According Rao [4] who said about desperate type of Gadaba Viz- the khattri Gadaba. Who lives near Bobbilli of Andhra Pradesh neighboring to Koraput district of Odisha.

Key words: Aboriginality, primitive, reconcile.

\section{Socio-Cultural Identity}

When we focus the socio-cultural identity we first go through their family life, food habits, agricultural Production, dress pattern and ornaments, dance, song and music, marriage and youth dormitory, Religious life, Rituals, festivals, Blind belief etc... All these play a key role. Their activities and achievements, their morals and discipline are of great value.

\section{Family Life}

The family system has played a vital role in the tribal society. Family is a component in the social formation and forms the first sphere in which individuals combine. Lowie [5] takes it to be as association that corresponds to the institution of marriage, the society approved forms of sex relation.

Radcliffe Brown [6] includes in a family a husband and wife with their child or children. Relationship with the latter is to be understood in a sociological rather than a physiological sense. As far as the Gadaba family is concerned, it still sustained to serve as an operative unit in the society. Monogamous family with a nuclear structure is the main feature of the Indian tribes. Family on the whole functions as an economic unit. There is a great co-relation between father and young son. The youngsters are brought up in the family by the parents till they are economically independent. When the grown up son marries he detached from his parents and established his new family. After that father and son do not work in a common land. A separate land is allotted to the son for financial support.

\section{Food habits}

The staple food of the Gadaba's are rice, millet and is supplemented by pulses like ragi(1). They also use mandia pej(2). They take their regular meal thrice a day. From about 9 a.m. to 10 a.m. they eat rice, curry with a cup of mandia pej(3). During 2 p.m. to 3 p.m. they take two or three glass of mandiapej and then take their dinner at about 8 p.m. Rice, curry is the men menu along with mandiapej. They also take non-veg. food item like meat, chicken, fish and egg during the festivals. They also collect some food materials like kandas and kolis(4) mango and mushrooms. They also use mahuli (Mohua liquor), landa (Mandia liquor), salap(Palm liquor) etc. They offer liquor to their deities but landa is not used for ritual functions only taken during marriages, harvests also.

Keywords: Components, manognous, ragi(fingermillet), maddia pej(elcusine corocana),

\section{Agricultural Production}

The Gadabas are primarily hill and upland fields cultivators. They followed two types cultivating process. Viz. settled cultivation as well as shifting cultivation. They live near the perennial hill streams and use the spring water to irrigate the land. Gadaba is the first community in Asia who started paddy cultivation. Along with rice and paddy they cultivate ragi(finger millet), alasi(Niger), khetjanna(bajara), kandul(dal), biri(blackgram) mung(green gram), sorisa(mustard) etc... They grow different types of vegetables and fruits such as brinzal, kumuda(pumpkin) lau(gourd) tomato and potato, fruits like mango, drumstick, papaya, banana, jackfruit etc.... For cultivation they use simple agricultural implements, namely the plough, spade, axe etc.... They are also the fond of fish and catch fish from ponds, streams, and river wherever available.

\section{Dress pattern and ornaments}

The traditional dress pattern of Gadaba is very simple and attractive also. Elder male members use a small piece of loin cloth called 'Lenguti' with a flap which hangs down in front. When they are busy in the agricultural work or at home, they also use Gamuchha(napkin). The female members use to wear long strip cloth locally known as 'Kerang'(Kerang fiber). They used two piece cloths. First piece round the waist and the second piece are worn across the breast. Godaba women are fond of wearing varieties of ornaments to beautify them. They wear ear rings, nose rings, finger rings and metal rings in their neck and necklace to which coin was attached as a pendant. These ornaments generally made out of brass and aluminum. They use brass made bangles. Hairclip 
(Khosa dang) big silver neck rings(khagala) Nose rings(Dandi) Black necklace(Tuitul) Red necklace(Bandara) Long necklace made with Ghungura(Gagura) etc... Traditionally wear neck rings which are about 500-700gms each and cannot be removed without the help of a blacksmith, as a part of their tradition it is only removed after their death.

\section{Dance, song and music}

Dance, song and music played a vital role of Gadabas aesthetic life. They are widely known for their Dhemsa dance. Each and every festival they perform Dhemsa dance. While performing the dance women wearing their famous traditional kerang sarees. 15 to 20 women forms a chain by joining hands all round and with a long hop spring towards the centre and then hop back to the full extent their arms, while they at the same time keep circling round and round. Dhemsa is performed to honor to the local deity. At the early time Gadaba dance was a type of wild jump, screaming, loud sought etc... They use various musical instruments consists of big drums, Tal, mudibaja, madal, flutes, Tamak and mahuri. They compose their own songs in Gutob Language. These entertainment dance show give expression to their internal sentiments, pleasure, affection, passion and their respect of beauty in nature.

\section{Marriage and youth Dormitory}

Marriage is very precious and played a significant role in Gadaba society. The Jala Dabu (Bride price) idea prevails in their section. They favour to marry their maternal uncle's daughter. At the time of marriage the newlywed husband has to pay certain amount of wealth to the bride's family. This is called bride price. The amount is fixed by the senior members of the bride's family. After fix up the price then the groom pays it as a traditional rule. They follow intermarriage or spousal relationship forms of marriage but marriage within the some clan (gotra) is also prohibited. They follow various forms of marriage such as:

- Marriage by negotiation (Ludiringnaie)

The marriage Settled by parents or guardians. Both Families should have different clan. Before marriage is settled, the opinion of the boy and the girl is also taken. The marriage date is fixed with the help of Dissari.

- $\quad$ Marriage by capture (Ann Ringnaie)

The boys who are not financially sound and cannot able to meet the marriage expenses or fall in love with a girl but the family of the girl does not approved it, the boy gets married by capturing the girl.

- Marriage by Service (Simandhi denka baielic Ludki Nangien)

This kind of marriage is known as 'Ghar Juain' it is relatively local odia term. When the bridegroom is poor and cannot afford the bride price or when the bride is only child to the family and has landed property and the father in law wishes to have a Ghar Juain.
- $\quad$ Marriage by Elopement(Udulia Vivah)

In this marriage a couple in love simple run away. Then their parents searching them, trace them and finally bring them back.

\section{Religious life}

The Gadabas believe that all human being have a soul which is called 'Atma' when a person dies the Atma leave from the body unless the cremation rites are accomplished the Atma remains nearby and becomes ghost (Duma) till they are performed gracefully. The Gadaba also believe the existence of Mahaprabhu the supreme power. They believe in polytheism. They worship different components of nature to gratify their pious needs.

Their village deity Nissani Munda is seated in the centre of the village. She is propitiated during all the rituals and festivals to protect the village from all calamities. They also propiate some deities of nature residing in tree, hills, forests, streams, rivers namely Dongardevta, Banadurga, Kamini, Gangama etc...

Before fishing and other agricultural festivals they worshipped kamini. For more and more production of crops, they worshipped Dasmati (the Goddess of earth) sutabhauni is worshipped the good output. Sun and moon also worshipped by them in certain occasions.

\section{Key words: Polytheism, pious, propitiated}

\section{Rituals}

Gadaba have many sacraments, Interconnected to agriculture man, god and Spirit (Dumas) of forefathers. In agricultural sacraments which is celebrated in difference agricultural performances such as conservation of seeds, ritual germination of pip(seeds), cultivating, pip showing, new crops etc... The spirit of dead ancestors is called duma. Those Dumas may either be evil and good types. When a person dies in the abnormal death such as falling from tree, drowning, killed by animals, suicide etc... their soul exists as evil duma and roaming in the forests and searching opportunities to harm the family members.

Second thing is life cycle. In the course of life between birth and death a Gadaba individual passes through successive phases and crises of life. They have their own rational view that human life begins in the mother's womb and ends with death. When a child comes to the Gadaba world, at the end of ninth day they worship Jamaraja. After that the name giving occasion, takes place. Dissari selects a name for the new born baby. There is a close connection between the two cultures (Gadaba culture and Odia culture). That is mother's brother (Mamu) has a vital role to play in this get together. He is specially invited and he gives a unique gift for the new born baby. 
There is some specialty in Death rituals. The dead are buried with their feet to the west. After cremation work is over the members stop on the way and a fish is boiled. This boiled fish is offered to the dead. An egg is smashed and placed on the ground. The house of the dead person is cleaned with cow dung. Mourning lasts for nine days. On the last day cow or bullock is killed with the blunt head of an axe. Some blood and cooked rice are put in the leaf-cups and placed on the graveyard.

There is some rigidity while observing puberty rites. The Gadaba observe puberty rites for adolescent girl gets maturity. The girl is scheduled in an isolated room where no one is allowed to go. This period continues for nine days. At the end of the ninth day the girl takes her purifying birth in the nearest river or hill stream with turmeric paste. She wears new clothes. Then the Dissari is invited there to perform the rites. When the ritual gets over a non- vegetarian feast is served where only the adults are allowed to eat. Invitees present her new clothes and cosmetics.

\section{Festivals}

The festivals, ceremonies at home and in the Gadaba village are a regular event followed from generation to generation. The important festivals are: Gotar Parab, Pus Parab, Chaita Parab etc.

Gotar Parab is celebrated in the commemoration of a dead person of their family. The observation of this ritual is extremely expensive; it requires more money and manpower. They sell their land, ornaments and do extra work to save money for the purpose. The main purpose of this festival is Salvation of 'Duma'. Ramdas wrote, "every Gadaba has to perform a great ceremony within three or four years after the death of his father. This ceremony is called Gotar." The son or the brother of the dead man, after the corpse has been disposed of, picks up a stone from the place where the dead body has been disposed of and preserves it carefully for the Gotar ceremony[79].

The 'Pus Parab' as the name signifies falls in the Pus month (Dec nnnnn - Jan) of the year. They worship 'Budhi Thakurani' the village deity and sacrifice chicken. Whole village actively participate in the Parab. During the occasion they engage themselves in cleaning of the houses, painting the walls and floor. The children dance with songs in the moonlit night. The young boys and girls go on begging village after village and collect rice and money. This activity continues for fifteen days. At the end of the day a grand feast takes place.

In the month of Chaitra, they celebrate a festival which is known as chaiti parab. Firstly one favorable date is fixed by the 'Dissari'. Secondly Goat, Sheep, Chicken and Pigeon etc. are assembled by the villagers. Kandula and Mahula flower are taken to the holy place and offered to the Supreme Being by the Pujari.

\section{Blind belief and superstition}

Blind belief and superstition have a great role for maintaining a smooth life.

- If a family member suffers from leprosy, his family is segregated by other villagers. After the demise of that individual a formal treat is given by the family members where goat, chicken, liquor etc. are offered to the village celestial being.

- They believe in worshiping Moon God with the help of 'Gurumai' when somebody is in full pain from fever.

- At the time of travelling if they see a jackal they trust it as impure and feel that the motive of their journey will not be fruitful.

Key words: segregated, demise, celestial being.

\section{Changing Scenario}

The Gadabas are no longer isolated from the world outside. In post independent era they being declared as a scheduled tribe of the state, they are influenced by a package of development and welfare programmes and their varied exposure to the developing world has made impacts in their traditional way of life.

- A number of projects such as "Micro Project for Development of the Primitive Tribal Group", "Modified Area Development Approach", 'OTELP', 'TDCCOL' etc. came into force.

- Department of SC \& ST Development has played a vital role. Several programmes were implemented to promote primary and secondary education for tribal children's of the state viz. Scholarship, hostel facilities, supply of books, uniforms, cots, beds, utensils etc. Special pre-examination and the prerecruitment coaching facility.

\section{CONCLUSION}

To conclude we can say that customization in Gadaba culture are distinctly observable in their languages, dress pattern, ornaments, food, festivals and rituals also. The peer group of the Gadabas is neglecting their original language. Modern progressive forces are energetically framing their lives. The whole Gadaba society at present moment is going through the censorious stage of transformation. A variety of modernizing forces have brought speedy transformation in their whole socio-cultural atmosphere. Cultural hybridization is on increase and this is sure to effect an appreciable change in the life style of Gadabas'. Changes brought through modern and technological outlook are the healthy symptom for development but at the same time awareness should be paid to maintain their traditional systems which have a massive value. The best characteristics of both the traditional and 
modern culture should be intermixture for their credible development.

Key words: Censorious, Hybridization, Intermixture.

\section{REFERENCES}

1. Thurston E. Castes and tribes of southern India. Government Press; 1909.

2. Elwin, Verrier: The Bondo Highlander, Oxford University Press, Bombay.1950.

3. Bell, RCS. Orissa District Gazetteer (Koraput), Govt. Press, Cuttack.1945.

4. Rao, Prasad DL. "An Analysis of Kinship, Economy and Religion of the Jatpus: A Scheduled
Tribe in Andhra Pradesh", Research Thesis, Andhra University.1970

5. Lowie, Robbert H. Social Organization, London, Routledge and kegan paul.1950; (1969 print).

6. Radcliffe, Brown: AR. "The study of kinship system", Journal of royal Anthropological Institute of Great Britain and Ireland. 1941; (71): 1-18

7. Ramdas G. "The Gadabas", Man in India, XI: $1931 ; 160-173$.

8. Padhi, Soubhagya Ranjan. The Gadaba Tribe of Orissa, Abhijeet Publications, Delhi.2011.

9. Vidyarthi LP, Rai Binaya Kumar. The Tribal Culture of India, Concept publishing company, New Delhi.1976. 